\title{
Analisis Kinerja Bangunan Rangka Baja dengan Bresing Tahan Tekuk terhadap Beban Gempa
}

\author{
ILHAM \\ Program Studi Teknik Sipil, Institut Teknologi Sains Bandung \\ Email: ilham.chaniago@gmail.com
}

\begin{abstract}
ABSTRAK
Penggunaan bresing tahan tekuk dapat menjadi solusi atas kebutuhan struktur tahan gempa di Indonesia. Disipasi energi pada elemen bresing tahan tekuk dilakukan melalui kinerja plastifikasi bagian inti bresing akibat beban tarik dan tekan. Penelitian ini berisi kajian kinerja dari bangunan rangka baja beraturan dengan bresing tahan tekuk (BRB) dengan variasi level ketinggian lantai yaitu 3 lantai, 8 lantai dan 15 lantai. Analisis struktur 3D dilakukan dengan dua prosedur analisis yaitu modal pushover dan nonlinear time history pada program ETABS. Hasil analisis menunjukkan bahwa pemilihan elemen BRB sangat mempengaruhi kinerja struktur, yang terlihat dari pola drift yang terjadi. Untuk struktur beraturan dengan berbagai ketinggian, tingkat kinerja struktur dengan BRB cukup baik, yaitu Immediate Occupancy (IO) akibat beban gempa rencana. Plastifikasi hanya terjadi pada BRB, dan kelelehan pada balok mulai terbentuk sampai mekanisme keruntuhan terjadi. Hasil modal pushover dengan nonlinear time history pada bangunan 15 lantai yang cukup mirip menunjukkan bahwa modal pushover dapat digunakan untuk memprediksi kinerja struktur BRB yang beraturan.
\end{abstract}

Kata kunci: kinerja struktur, bresing tahan tekuk, immediate occupancy, modal pushover, nonlinear time history

\begin{abstract}
Buckling restrained braces (BRB) can be an alternative solution for earthquake resistant steel structure in Indonesia. The energy dissipation for buckling restrained elements is conducted through yielding of the core due to tension or compression forces. This study presents an evaluation of the structural performance of steel structures with BRB varying in heights, 3-story, 8-story and 15-story. The 3D structural analysis was carried out with ETABS software using 2 methods, Modal Pushover and Nonlinear Time History. The results shows that the selection of BRB elements greatly affected the structural performance, showed by the drift pattern. For regular structures with variation in heights, structures with BRB behaved satisfactory under the design load with the performance level of Immediate Occupancy (IO). Yielding was limited to BRB members, and afterwards the yielding occurred on beams until collapse. The results of modal pushover and time history analysis for 15-story structure are similar, thus modal pushover can be used to predict the performance of regular structural system with BRB.
\end{abstract}

Keywords: structural performance, buckling restrained brace, immediate occupancy, modal pushover analysis, nonlinear time history analysis 


\section{PENDAHULUAN}

Dalam beberapa tahun terakhir, desain seismik bangunan telah mengalami perubahan yang signifikan karena meningkatnya permintaan untuk optimalisasi kemampuan struktur bangunan untuk meminimalkan tingkat kerusakan, kerugian ekonomi, dan biaya perbaikan struktur akibat gempa bumi. Para insinyur mulai menggunakan desain berbasis kinerja (Performance Based Design) sebagai metode desain seismik alternatif. Desain berbasis kinerja merupakan metode desain yang lebih komprehensif dimana kriteria desain didasarkan pada pencapaian tujuan kinerja tertentu ketika struktur diberikan pada tingkat bahaya seismik tertentu. Untuk merancang bangunan seismik alternatif tersebut, material penyusun struktur bangunan mempunyai peranan penting pada kinerja keseluruhan struktur.

Dalam mendesain bangunan baja, kelangsingan dari elemen strukturnya menjadi hal penting untuk diperhatikan. Kelangsingan sangat berpengaruh pada permasalahan tekuk untuk kondisi pembebanan tekan. Kehadiran bresing tahan tekuk (BRB) merupakan solusi dari permasalahan tekuk pada bresing. Penggunaan BRB sudah banyak digunakan di Amerika dan Jepang, dikembangkan untuk memperbaiki kinerja struktur rangka baja lainnya seperti struktur rangka pemikul momen dan struktur rangka berpengaku konsentrik dalam hal kekuatan, daktilitas dan disipasi energi. Pendisipasian energi dilakukan melalui kinerja plastifikasi bagian inti bresing (akibat beban tarik dan tekan), dimana permasalahan tekuk pada bresing diakomodasi dengan adanya selongsong penahan tekuk. Penggunaan bresing tahan tekuk ini dapat menjadi solusi atas kebutuhan struktur tahan gempa, baik untuk pembangunan struktur baru maupun untuk perkuatan dan perbaikan struktur yang sudah ada.

\section{TINJAUAN PUSTAKA}

\subsection{Perencanaan Struktur Penahan Beban Lateral}

Salah satu aspek penting dalam merekayasa struktur bangunan tahan gempa adalah daktilitas. Baja merupakan material yang paling daktail seringkali digunakan dalam rekayasa material oleh para profesional. Pada konsep perancangan struktur bangunan tahan gempa, struktur harus mampu memikul beban yang bekerja, antara lain beban gravitasi dan beban lateral. Beban gravitasi terdiri dari beban mati dan beban hidup, sedangkan beban lateral terdiri dari beban angin dan beban gempa.

\subsection{Daktilitas Struktur $(\mu)$}

Daktilitas struktur merupakan konsep yang diadopsi dari AISC 2005 untuk merancang struktur bangunan tahan gempa. Dengan pengaplikasian konsep ini, komponen struktur tertentu dimungkinkan untuk mengalami plastifikasi (kerusakan) sebagai sarana disipasi energi gempa yang diterima oleh struktur saat gempa kuat terjadi. Namun demikian, struktur diharapkan tidak mengalami keruntuhan.

\subsection{Respon Inelastis Struktur}

Pada umumnya struktur dirancang dengan tingkat daktilitas tertentu untuk dapat menjadi plastis saat terjadi gempa kuat.

\subsection{Kekakuan}

Kekakuan merupakan gaya yang dapat disimpan oleh sistem struktur, jika struktur diberi perpindahan seperti perpanjangan, perpendekan, perputaran sudut, atau deformasi lainnya.

\subsubsection{Kekuatan}

Kekuatan merupakan ketahanan baik struktur maupun komponen struktur, atau material yang digunakan terhadap beban. 


\subsubsection{Sistem Pengaku Bresing}

Sistem struktur baja tahan gempa memiliki kinerja yang sangat baik, karena material baja memiliki daktilitas dan kekuatan yang tinggi dibandingkan dengan material lain. Terdapat tiga sistem struktur baja tahan gempa:

1. Sistem rangka baja penahan momen.

2. Sistem rangka baja pengaku konsentrik.

3. Sistem rangka baja pengaku eksentrik.

\subsection{Rangka Bresing Tahan Tekuk (BRBF)}

\subsubsection{Konsep Bresing Tahan Tekuk (BRB)}

Konsep rangka bresing tahan tekuk merupakan pengembangan dari sistem rangka bresing konsentrik. Konsep ini dimaksudkan untuk mengatasi permasalahan tekuk pada bresing yang akibat gaya tekan. Untuk mengatisipasi permasalahan tekuk dengan baik, maka nilai kelangsingan yang pada bresing harus diminimalkan dengan memperbesar luas penampang bresing, seperti menambahkan selongsong pada inti baja (berupa mortar atau beton).

Sebuah BRB terdiri dari inti baja yang memberikan ketahanan aksial dibatasi oleh casing besi beton penuh yang memberikan ketahanan lentur dan tekuk. BRB memiliki daktilitas yang cukup besar karena ikatan antara inti baja dan beton sekitarnya, Gambar 1 menunjukkan detail khas BRB. Sistem ini memberikan kekuatan dan kekakuan untuk mencegah tekuk global dan lokal serta sendi plastis yang terkait dengan tekuk, hasil degradasi minimal kekuatan dan kekakuan dari BRB serta tarik dan tekan kapasitas yang sama (Asgarian dan Amirhesari 2008).

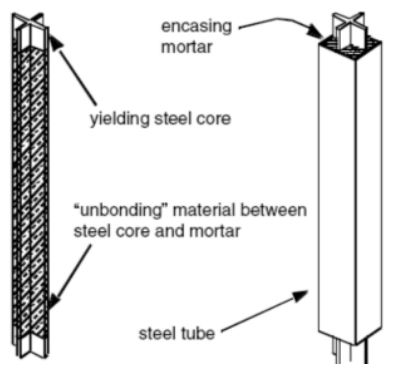

\section{Gambar 1. Konsep buckling restrained braces}

(Sumber: FEMA 356, 2000)

\subsubsection{Komponen Buckling Restrained Brace (BRB)}

Menurut Bertero (2004) komponen Buckling Restrained Braces terdiri dari 5 komponen yaitu:

1. Segmen terkekang-leleh

Segmen ini berupa baja berbentuk persegi atau salib, dengan satu pelat baja atau lebih di sekelilingnya yang disebut casing seperti terlihat pada Gambar 2. Karena segmen ini dirancang leleh saat dibebani siklik, maka material yang memiliki daktilitas yang tinggi dapat digunakan seperti baja ringan ( $A 36$ atau baja kekuatan rendah) ataupun baja kekuatan tinggi (A572 Gr50). Hal ini penting untuk merancang kinerja BRB yang dapat diandalkan. 


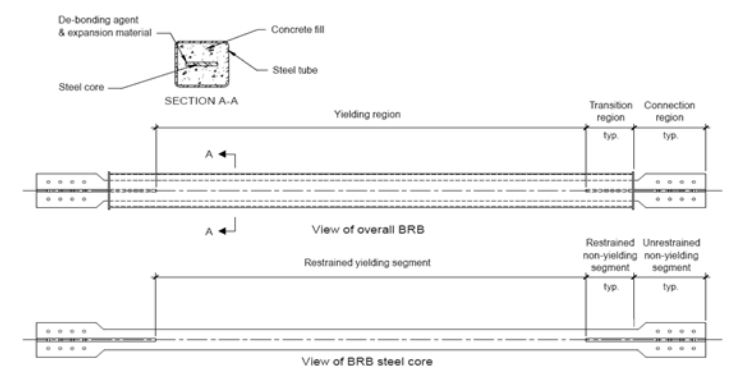

\section{Gambar 2. Komponen buckling restrained braces}

(Sumber: Wada, et al., 1998)

2. Segmen terkekang-tidak leleh

Segmen ini diselimuti oleh casing dan mortar, biasanya merupakan perpanjangan dari segmen terkekang-leleh dengan area yang diperbesar berfungsi untuk memungkinkan respon elastis. Peningkatan area ini dengan adanya pengaku yang dilas.

3. Segmen tidak terkekang-tidak leleh

Segmen ini biasanya merupakan perpanjangan dari segmen terkekang-tidak leleh, disebut juga proyeksi inti baja. Segmen ini dirancang dengan sambungan baut untuk memudahkan proses ereksi di lapangan dan mencegah terjadinya tekuk lokal. Namun demikian, dimungkinkan untuk dirancang dengan sambungan lain seperti pin atau las.

4. Casing dan pengisi pencegah tekuk

Inersia material yang efektif dapat meminimalkan atau menghilangkan transfer gaya geser antara segmen baja tahanan. Adapun material yang sering digunakan yaitu karet, polietilen dan silikon grease. Segmen ini menghasilkan tekuk yang kecil karena mekanisme penahanan. Gap ini harus cukup besar sehingga dimungkinkan perluasan dari inti baja menghasilkan tekan. Dalam merancang gap, rasio Poisson bernilai 0,3 (elastis) dan 0,5 (leleh).

5. Mekanisme tekuk-terkekang

Mekanisme ini biasanya berisi mortar dan casing baja. Mekanisme tekuk terkekang dapat dilihat pada Gambar 3 di bawah ini.

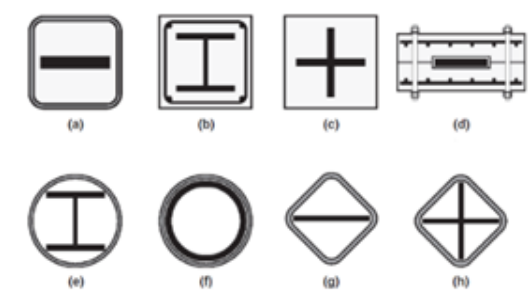

Gambar 3. Penampang berbagai macam buckling restrained braces yang berkembang (Sumber: Chen, C. C., Chen S. Y. \& Liaw, J. J., 2001)

\subsubsection{Desain Struktur dengan BRB}

Dalam penelitian ini, jenis konfigurasi BRB yang digunakan yaitu tipe inverted $\mathrm{V}$-braced frame. BRB dipasang dari sisi bawah bagian kiri dan kanan portal sampai sisi atas bagian tengah portal. Bentuk bresing tipe inverted V-braced frame dimodelkan seperti pada Gambar 4. 


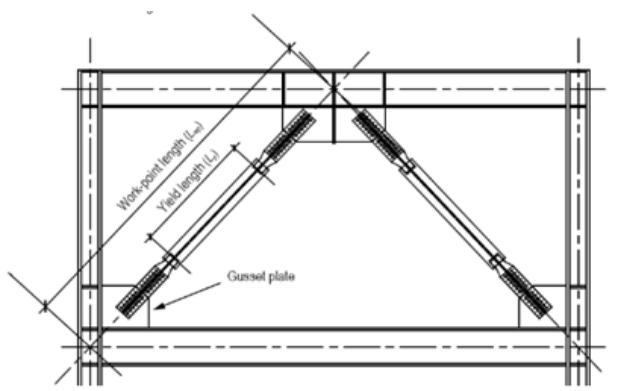

Gambar 4. Bresing tipe inverted V-braced frame

(Sumber: Lopez, W. A. \& Sabelli, R., 2004)

\section{METODOLOGI}

Dalam penyusunan penelitian ini, dibutuhkan langkah-langkah yang sistematis dan terarah sehingga akan diperoleh hasil penelitian yang sesuai dengan tujuan penelitian. Adapun langkah-langkah kajian penelitian terlihat pada Gambar $\mathbf{5}$ berikut.
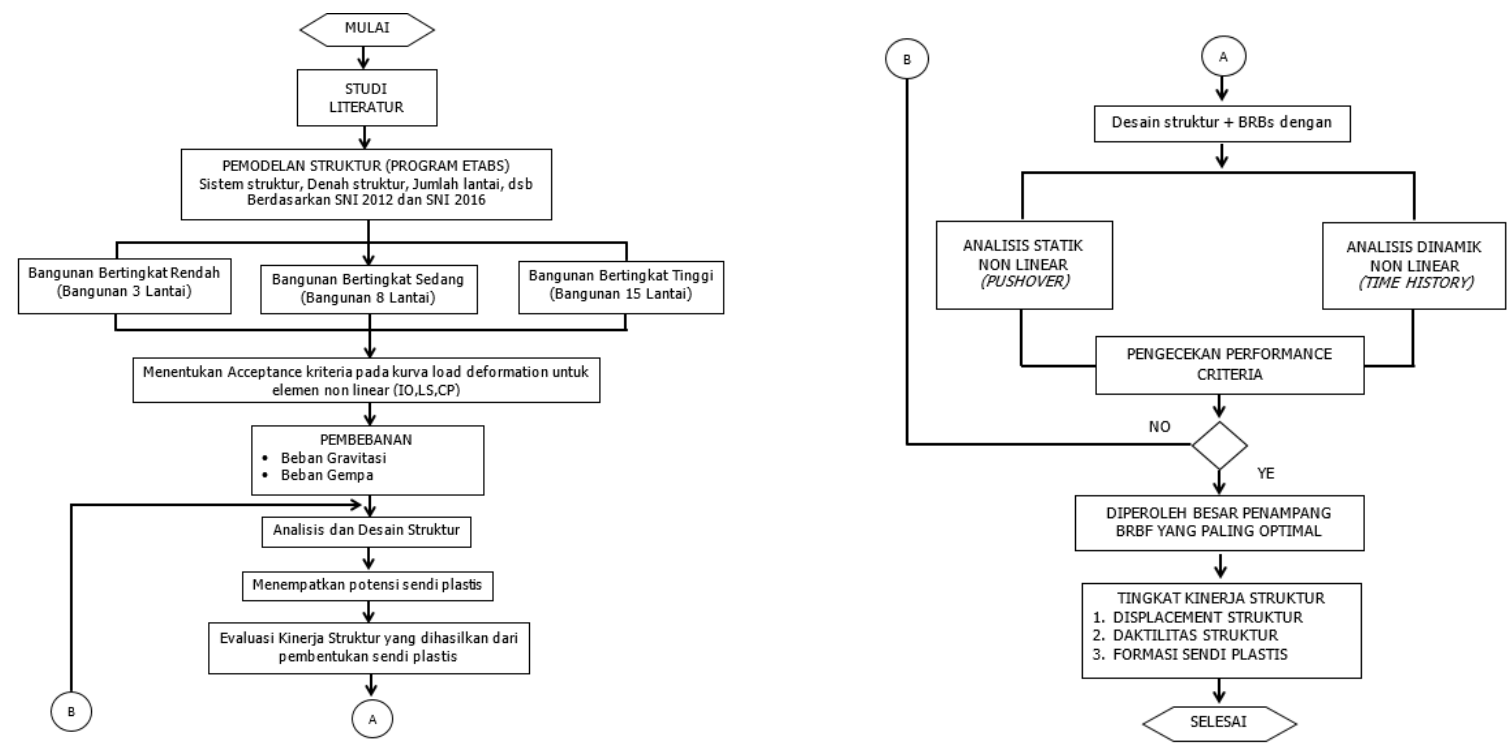

Gambar 5. Diagram alir penelitian

\subsection{Deskripsi Model Struktur dan Lokasi}

Dalam pemodelan bangunan ini terdapat tiga variasi jumlah lantai bangunan yaitu 3 lantai, 8 lantai, dan 15 lantai dengan bentuk dan ukuran denah yang sama yaitu $54 \mathrm{~m}$ untuk arah $\mathrm{Y}$ dan $45 \mathrm{~m}$ pada arah X (panjang tiap bentang adalah $9 \mathrm{~m}$ ) terlihat pada Gambar 6. Bangunan ini akan digunakan sebagai perkantoran kategori II dimana faktor keutamaan strukturnya adalah 1,0. Bangunan terletak di daerah Jakarta dengan jenis tanah sedang. Tinggi lantai tipikal bangunan adalah $4 \mathrm{~m}$ dan tinggi untuk lantai dasar adalah $5 \mathrm{~m}$, pada lantai pertama 
menggunakan dinding kaca dan lantai di atasnya terdiri dari cladding beton pracetak.

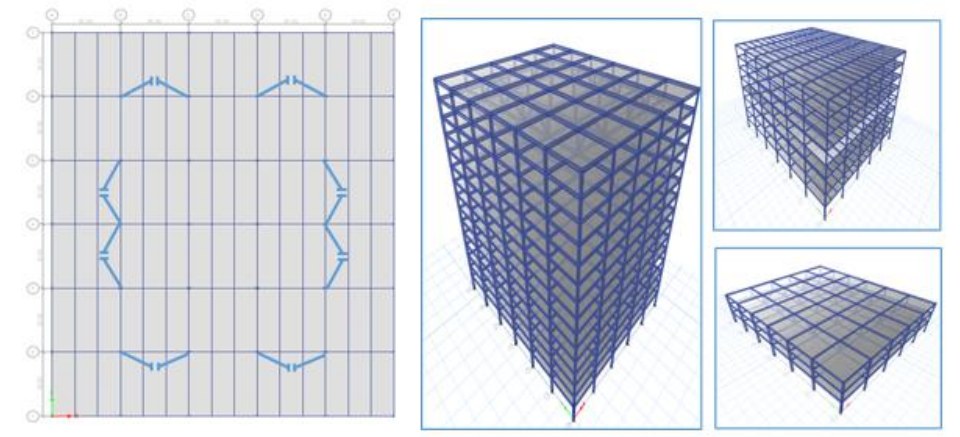

Gambar 6. Denah dan model 3D bangunan dengan ketinggian yang berbeda

\subsection{Pembebanan Struktur}

Beban-beban yang direncanakan bekerja pada struktur gedung tergantung dari fungsi ruangan, lokasi, bentuk, kekakuan, massa, dan ketinggian gedung itu sendiri.

\subsubsection{Beban mati}

Beban mati adalah berat sendiri struktur berasal dari material yang digunakan dan beban mati tambahan yang bekerja pada struktur. Pada software ETABS, berat sendiri struktur dihitung secara otomatis berdasarkan input data material dan dimensi penampang yang digunakan.

\subsubsection{Beban mati tambahan}

Beban mati tambahan adalah beban tambahan lain yang membebani struktur secara tetap, antara lain finishing lantai dan dinding. Dalam perencanaan ini, beban mati tambahan yang diperhitungkan antara lain keramik, spesi, plafond dan penggantung, mekanikal elektrikal, serta dinding $1 / 2$ bata.

\subsubsection{Beban hidup}

Beban hidup adalah beban akibat penghunian atau penggunaan struktur gedung. Beban pada lantai yang berasal dari barang yang dapat berpindah, mesin, serta peralatan. Beban ini tidak dapat terpisahkan dari gedung dan dapat diganti selama masa layan. Untuk bangunan perkantoran, beban hidup yang digunakan sebesar $250 \mathrm{~kg} / \mathrm{m}^{2}$.

\subsubsection{Beban gempa}

Analisis struktur terhadap beban gempa menggunakan metode respons spektrum sesuai SNI 1726:2012. Respons spektrum gempa rencana dikalikan dengan faktor koreksi $I / R$. $I$ merupakan faktor keutamaan ( $I=1,0$ untuk perkantoran), sedangkan $R$ merupakan faktor reduksi gempa representatif dari struktur yang bersangkutan $(R=8$ untuk bangunan rangka baja dengan bresing terkekang terhadap tekuk).

\subsubsection{Kombinasi pembebanan}

Untuk mendapatkan pengaruh maksimum pada struktur akibat beban yang bekerja, perlu diperhitungkan beberapa kombinasi pembebanan sesuai dengan SNI 1726:2012. Halmana untuk analisis gempa perlu diperhitungkan gempa horisontal dan gempa vertikal.

\subsection{Model ETABS}

Program analisis struktur ETABS digunakan untuk model struktur untuk analisis nonlinier pushover dan analisis nonlinier time history. Berikut ini adalah deskripsi dari model komputer serta asumsi pemodelan yang dibuat:

1. Gaya gempa yang diberikan pada pusat massa pada setiap diafragma sebagai titik beban 
memperhitungkan torsi ( $5 \%$ eksentrisitas).

2. $5 \%$ modal redaman diaplikasikan pada struktur, meskipun redaman $2 \%$ akan lebih realistis untuk struktur BRB dari redaman struktur yang dicatat dalam perilaku histeresis dari BRB.

3. Bresing dimodelkan sebagai pinned end.

4. Sambungan balok dan kolom dimodelkan sebagai welded unreinforced flange (wuf) sepanjang grid dimana bresing dipasang.

5. Kekakuan efektif dari BRB didefinisikan 1,66 kali dari kekakuan inti baja.

6. Elemen dan kurva koneksi gaya-perpindahan dihitung menggunakan ASCE 41-06 Tabel 56 dan Tabel 5-7 untuk melakukan prosedur statis nonlinier. Hubungan gaya-perpindahan untuk komponen baja yang digunakan untuk semua komponen utama non BRB.

7. Pendefenisian elemen BRB sebagai section designer, sedangkan segmen terkekang dan leleh (bagian ujung-ujung) hanya didefinisikan sebagai section steel core.

\subsection{Pemodelan Inelastis Elemen Struktur}

Analisis inelastis struktur dibuat berdasarkan hasil desain elastis dengan tujuan mengetahui kinerja secara struktur maupun elemen yang sudah berperilaku nonlinier menggunakan program ETABS. Elemen struktur dengan model inelastis antara lain balok, kolom, dan bresing tahan tekuk.

\subsubsection{Pemodelan inelastik balok dan kolom}

Nilai properti untuk pemodelan sendi plastis sebagai default hinge berdasarkan FEMA 356 terlihat pada Gambar 7. Penjabarannya adalah sebagai berikut:

1. Kolom, sendi plastis terbentuk pada kedua ujung akibat kombinasi lentur dan tekan sehingga didefinisikan sebagai PMM.

2. Balok, sendi plastis terbentuk pada kedua ujung akibat momen lentur sehingga didefinisikan sebagai M3.
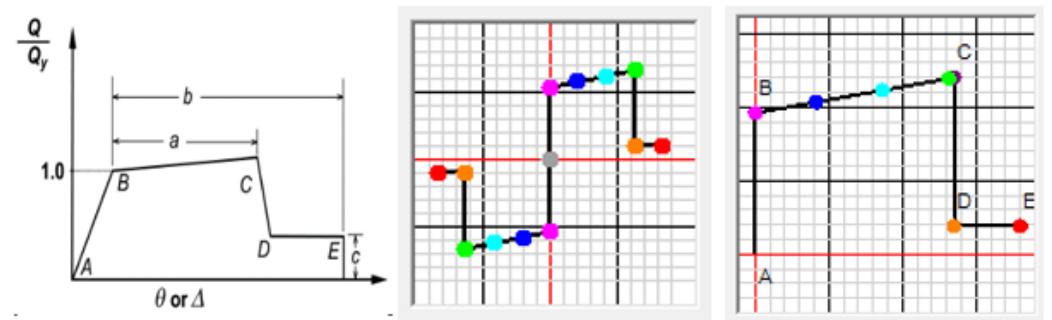

Gambar 7. Denah dan model 3D bangunan dengan ketinggian yang berbeda (Sumber: FEMA 356,2000)

\subsubsection{Pemodelan inelastik bresing}

Level kinerja pada bresing ditentukan dalam ASCE 41-06 seperti terlihat pada Tabel 1 berikut:

Tabel 1. Level Kinerja Bresing

\begin{tabular}{lcc}
\hline & $\begin{array}{c}\text { Level Kinerja } \\
\text { Bresing Tarik }\end{array}$ & $\begin{array}{c}\text { Level Kinerja } \\
\text { Bresing Tekan }\end{array}$ \\
\hline Yield (Y) & $\Delta_{y}$ & $\Delta_{y}$ \\
\hline Immediate Occupancy (IO) & $0,5 \Delta_{y}$ & $0,5 \Delta_{y}$ \\
\hline Life Safety (LS) & $8 \Delta_{y}$ & $10 \Delta_{y}$ \\
\hline Collapse Prevention (CP) & $10 \Delta_{y}$ & $13 \Delta_{y}$ \\
\hline
\end{tabular}

Gambar 8 menunjukkan nilai properti untuk pemodelan sendi plastis sebagai default hinge pada bresing berdasarkan FEMA 356. 

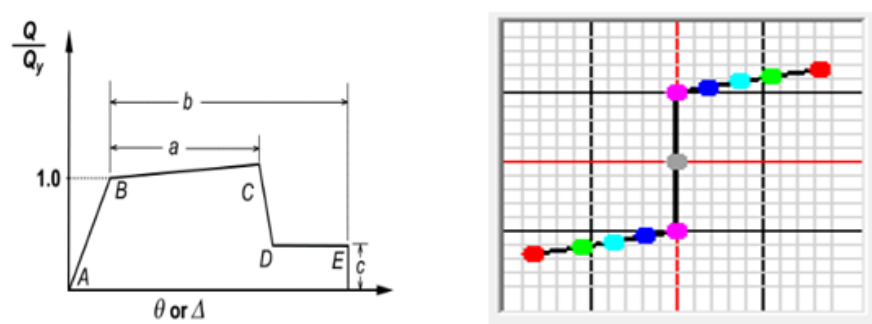

Gambar 8. Contoh input sendi plastis bresing berdasarkan FEMA 356

(Sumber: FEMA 356, 2000)

\section{ANALISIS DAN PEMBAHASAN}

\subsection{Evaluasi Beban Gempa}

Evaluasi beban gempa berdasarkan SNI 1726:2012 ditentukan dengan persamaan $V=$ $0,0251 \mathrm{~W}$ untuk bangunan 15 lantai, $V=0,031 \mathrm{~W}$ untuk bangunan lantai 8 dan $V=0,071 \mathrm{~W}$ untuk bangunan lantai 3. Berat struktur $W$ diperoleh dengan menghitung beban mati sebesar $100 \%$ dan beban hidup sebesar $30 \%$.

Tabel 2. Pengecekan Gaya Geser Setelah Dikoreksi

\begin{tabular}{|c|c|c|c|c|c|c|}
\hline Story & Tipe Be & Gempa & $\begin{array}{c}V_{d x} \\
{[\mathbf{k N}]}\end{array}$ & $\begin{array}{c}V_{d y} \\
{[\mathbf{k N}]}\end{array}$ & $\begin{array}{c}85 \% V_{s x} \\
{[\mathrm{kN}]}\end{array}$ & $\begin{array}{c}85 \% V_{s x} \\
{[\mathrm{kN}]}\end{array}$ \\
\hline \multirow{4}{*}{3 lantai } & \multirow{2}{*}{ Statik } & EQ-X & $2.699,92$ & 809,98 & $2.294,93$ & 688,48 \\
\hline & & $E Q-Y$ & 809,98 & $2.699,92$ & 688,48 & $2.294,93$ \\
\hline & \multirow{2}{*}{ Dinamik } & RSP-X & $2.738,99$ & 727,55 & & \\
\hline & & RSP-Y & 713,70 & $2.425,16$ & & \\
\hline \multirow{4}{*}{8 lantai } & \multirow{2}{*}{ Statik } & EQ-X & $3.381,77$ & $1.226,48$ & $2.874,51$ & $1.042,51$ \\
\hline & & $E Q-Y$ & $1.014,53$ & $4.088,27$ & 862,35 & $3.475,03$ \\
\hline & \multirow{2}{*}{ Dinamik } & RSP-X & $2.876,61$ & 960,10 & & \\
\hline & & RSP-Y & 945,50 & $3.506,36$ & & \\
\hline \multirow{6}{*}{15 lantai } & \multirow{2}{*}{ Statik } & EQ-X & $4.064,68$ & $1.219,45$ & $3.454,97$ & $1.036,53$ \\
\hline & & EQ-Y & $1.219,40$ & $4.064,83$ & $1.306,49$ & $3.455,10$ \\
\hline & \multirow{4}{*}{ Dinamik } & RSP-X & $3.867,02$ & $1.306,51$ & & \\
\hline & & RSP-Y & $1.160,11$ & $4.355,03$ & & \\
\hline & & TH-X & $3.465,73$ & $1.408,81$ & & \\
\hline & & $\mathrm{TH}-\mathrm{Y}$ & 765,49 & $3.457,46$ & & \\
\hline
\end{tabular}

Dari hasil perhitungan gaya geser dasar struktur statik $\left(V_{s}\right)$ dan dinamik $\left(V_{d}\right)$, dapat diketahui bahwa nilai $V_{d}$ respon spektra lebih besar dari $0,85 V_{s}$, maka $V_{d}$ akibat respon spektra tidak perlu lagi dikalikan dengan faktor koreksi sedangkan $V_{d}$ akibat analisis riwayat waktu $V_{d}$-nya lebih kecil dari $0,85 V_{s}$ maka gempa dinamik tersebut harus dikalikan dengan faktor koreksi skala sebesar $0,85 V_{s}$ dibagi dengan $V_{d}$ akibat analisis riwayat waktu untuk masing-masing arah. Dari hasil analisis pada Tabel $\mathbf{2}$ di atas, dapat disimpulkan bahwa nilai gaya geser yang terjadi sudah memenuhi persyaratan.

\subsection{Evaluasi Kinerja Struktur}

Pada Pasal 7.8.6 SNI 1726:2012 disebutkan bahwa simpangan antar lantai tingkat desain dihitung sebagai perbedaan defleksi pada pusat massa di tingkat teratas dan terbawah yang ditinjau. Besarnya nilai simpangan antar tingkat yang diizinkan ditentukan berdasarkan Tabel 
16 pada SNI 1726:2012. Berikut merupakan grafik simpangan pada arah-X dan arah-Y.

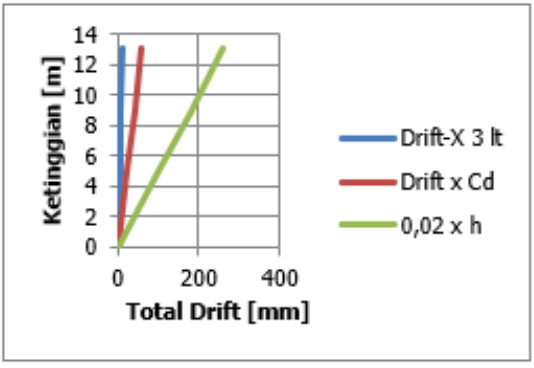

(a)

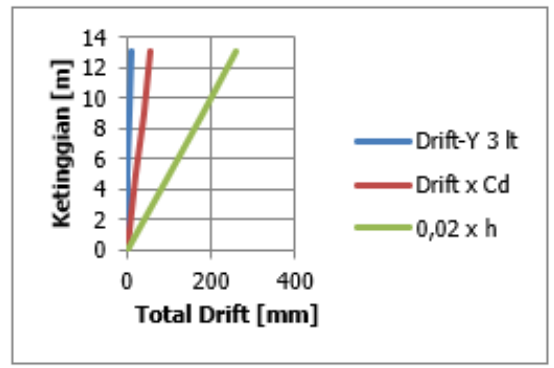

(b)

Gambar 9. Grafik total drift terhadap ketinggian bangunan (a) $\operatorname{arah} \mathrm{X}$ (b) $\operatorname{arah} \mathrm{Y}$

Gambar 9 menunjukkan perpindahan horizontal akibat beban gempa arah $\mathrm{X}$ dan arah $\mathrm{Y}$ lebih kecil dari perpindahan horizontal maksimum setelah dikalikan nilai $C_{d}$ sebesar 5 dan masih jauh lebih kecil dari batas maksimum $2 \%$ dari ketinggian.

\subsection{Desain BRB}

Desain BRB meliputi desain geometri (panjang segmen leleh $L_{y s}$ ), properti penampang baja inti, luas baja inti terpasang $\left(A_{s c}\right)$, tipe BRB, kapasitas tarik dan tekan maksimum, faktor kekuatan untuk BRB, serta kekuatan BRB (kuat tekan = kuat tarik). Panjang segmen leleh bresing berdasarkan regangan star seismic design untuk BRB yaitu $L_{y}=0,7 L_{w p}$, sedangkan preliminary design bresing digunakan tipe bresing dan ukuran bresing yang sudah diproduksi oleh star seismic design terlihat pada Tabel 3 hingga Tabel 5 berikut.

Tabel 3. Perhitungan Faktor Kekuatan untuk BRB pada Bangunan Lantai 3

\begin{tabular}{|c|c|c|c|c|c|c|c|}
\hline Lantai & $\begin{array}{c}\text { Luasan } A_{s c} \\
\text { terpasang } \\
\text { (star } \\
\text { seismic) }\end{array}$ & $\begin{array}{c}\text { Member } \\
\text { force check } \\
\begin{array}{c}N_{p l}=A_{s c} * \\
f_{y} \\
{[N]}\end{array}\end{array}$ & $\begin{array}{c}L_{w p} \\
{[\mathbf{m m}]}\end{array}$ & $\begin{array}{l}L_{y} \\
=0,7 L_{w p}\end{array}$ & $\begin{array}{l}\Delta_{b x} \\
=\left(P_{x} L_{y}\right) /\left(E A_{s c}\right)\end{array}$ & $\begin{array}{l}\Delta_{b m} \\
=C_{d} \Delta_{b x}\end{array}$ & $\begin{array}{l}\xi B R C \\
=2,0 \Delta_{b m} / L_{y}\end{array}$ \\
\hline 3 & 2 in & $338.063,84$ & $6.202,2$ & $4.341,5$ & 2,97 & 14,84 & 0,00684 \\
\hline 2 & 5 in & $845.159,60$ & $6.202,2$ & $4.341,5$ & 2,49 & 12,46 & 0,00574 \\
\hline 1 & 7,5 in & $1.267 .739,40$ & $6.986,8$ & $4.890,8$ & 2,82 & 14,08 & 0,00576 \\
\hline
\end{tabular}

Tabel 4. Perhitungan Faktor Kekuatan untuk BRB pada Bangunan Lantai 8

\begin{tabular}{|c|c|c|c|c|c|c|c|}
\hline Lantai & $\begin{array}{c}\text { Luasan } A_{s c} \\
\text { terpasang } \\
\text { (star } \\
\text { seismic) }\end{array}$ & $\begin{array}{c}\text { Member } \\
\text { force check } \\
\boldsymbol{N}_{p l}=A_{s c} * \\
f_{y} \\
{[N]}\end{array}$ & $\begin{array}{c}L_{w p} \\
{[\mathrm{~mm}]}\end{array}$ & $\begin{array}{l}L_{y} \\
=0,7 L_{w p}\end{array}$ & $\begin{array}{l}\Delta_{b x} \\
=\left(\boldsymbol{P}_{x} \boldsymbol{L}_{y}\right) /\left(\boldsymbol{E} \boldsymbol{A}_{s c}\right)\end{array}$ & $\begin{array}{l}\Delta_{b m} \\
=C_{d} \Delta_{b x}\end{array}$ & $\begin{array}{l}\xi B R C \\
=2,0 \Delta_{b m} / L_{y}\end{array}$ \\
\hline Roof & 2 in & $338.063,84$ & $6.202,2$ & $4.341,5$ & 2,97 & 14,84 & 0,00684 \\
\hline 6 & 3,5 in & $501.611,72$ & $6.202,2$ & $4.341,5$ & 2,49 & 12,46 & 0,00574 \\
\hline 5 & 5,5 in & $929.675,56$ & $6.202,2$ & $4.341,5$ & 2,82 & 14,08 & 0,00576 \\
\hline 4 & 7,5 in & $1.267 .739,40$ & $6.202,2$ & $4.341,5$ & & & \\
\hline 3 & 9,5 in & $1.605 .803,24$ & $6.202,2$ & $4.341,5$ & & & \\
\hline 2 & 12 in & $2.028 .383,04$ & $6.202,2$ & $4.341,5$ & & & \\
\hline 1 & 13 in & $2.197 .414,96$ & $6.202,2$ & $4.341,5$ & & & \\
\hline Base 2 & 14 in & $2.366 .446,88$ & $6.986,8$ & $4.890,8$ & & & \\
\hline
\end{tabular}


Tabel 4. Perhitungan Faktor Kekuatan untuk BRB pada Bangunan Lantai 15

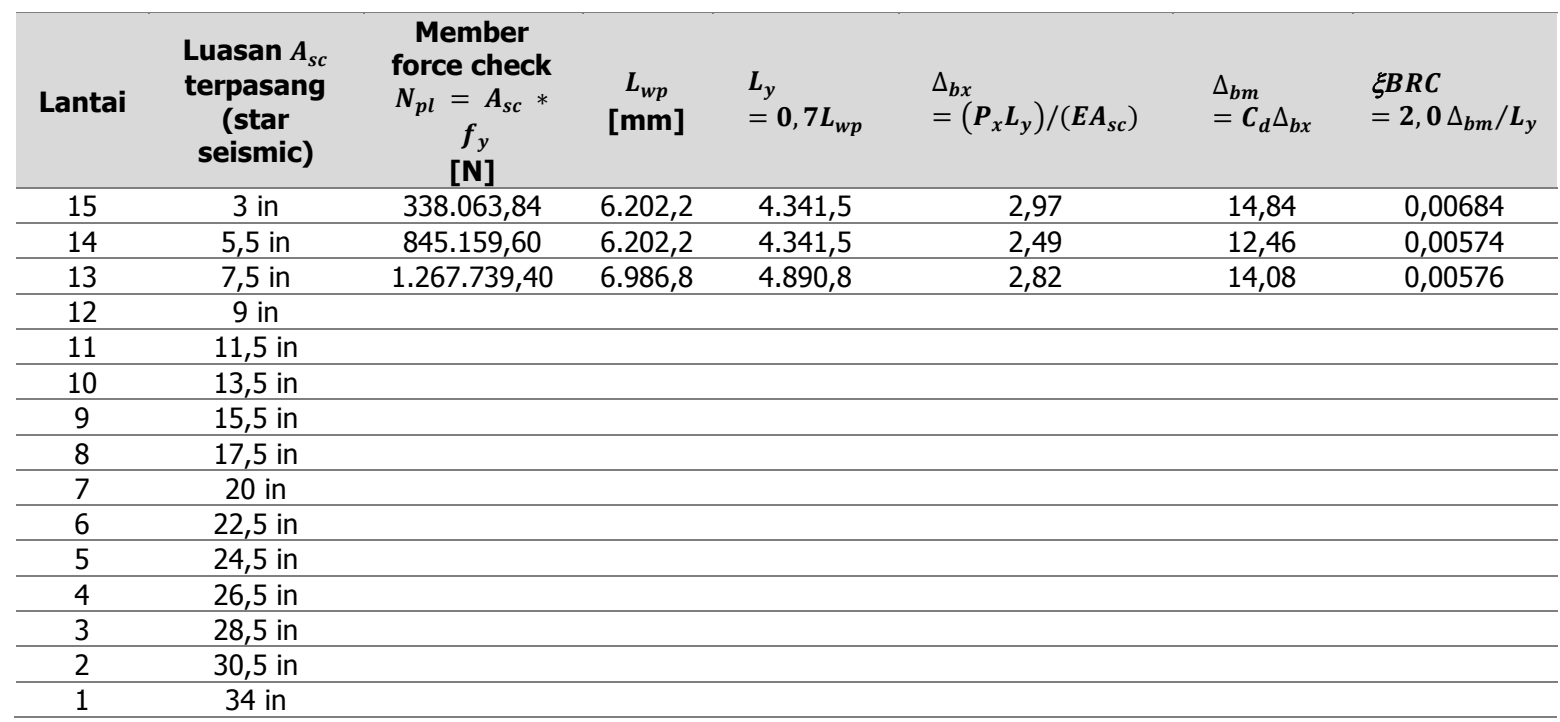

\subsection{Target Peralihan Metode Spektrum Kapasitas}

Gambar 11 menunjukkan hasil analisis target peralihan dengan metode spektrum kapasitas diperoleh sebesar $\delta_{t}=1.979 \mathrm{~m}$ dan $V_{t}=29.845,66 \mathrm{kN}$ dan waktu getar alami $\left(T_{e}\right)$ diperoleh sebesar 0,532 detik untuk bangunan tingkat $3 ; \delta_{t}=8.118,9 \mathrm{~m}$ dan $V_{t}=48.225,7848 \mathrm{kN}$ dan $T_{e}$ diperoleh sebesar 1,32 detik untuk bangunan tingkat $8 ; \delta_{t}=8.118,9 \mathrm{~m}$ dan $V_{t}=$ $50.858,6697 \mathrm{kN}$ dan $T_{e}$ diperoleh sebesar 1,854 detik untuk bangunan tingkat 15. Maka, dapat disimpulkan perilaku struktur arah $\mathrm{X}$ saat terjadi gempa masih dalam keadaan elastis.
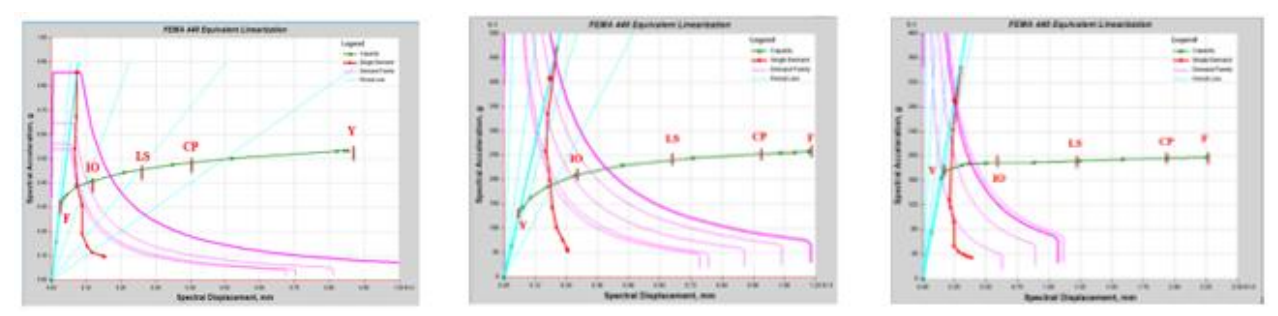

Gambar 11. Spektrum kapasitas arah gempa $Y$ untuk bangunan 3, 8 dan 15 lantai

\subsection{Sebaran Sendi Plastis}

Gambar 12 menunjukkan sebaran dan urutan sendi plastis pada analisis pushover untuk perilaku struktur yang direncanakan. Kelelehan pertama terjadi pada bresing sampai saat terjadinya kelelehan terakhir pada bresing tersebut kemudian diikuti balok pertama kali leleh. Untuk bangunan lantai 8, kelelehan pertama kali terjadi pada bresing sampai hampir $60 \%$, kemudian ditandai kelelehan pertama pada balok. Untuk bangunan lantai 15, kelelehan pertama kali terjadi pada bresing sampai hampir $40 \%$, kemudian ditandai kelelehan pertama pada balok lainnya. Kolom dalam portal bresing dan portal-portal lainnya tidak mengalami kelelehan sampai keruntuhan terjadi. Dari mekanisme sebaran sendi plastis yang terbentuk hasil analisis pushover untuk bangunan 15 lantai bahwa kelelehan pertama kali terjadi di bresing paling bawah yaitu pada step ke 3 dengan $V=31.737,2382 \mathrm{kN}$ pada perpindahan 278,5 mm; kemudian proses berjalan sampai terbentuknya performance point pada step ke 5 dengan $V=37.229,5365 \mathrm{kN}$ dan perpindahan maksimum adalah $516,8 \mathrm{~mm}$. Pada performance 
point ini level kinerja dari struktur adalah Immediate Occupancy (IO), selanjutnya struktur didorong sampai kondisi ultimit dimana terdapat 44 joint pada bresing yang sudah mencapai leleh sebelum terbentuknya kelelehan pertama pada balok.
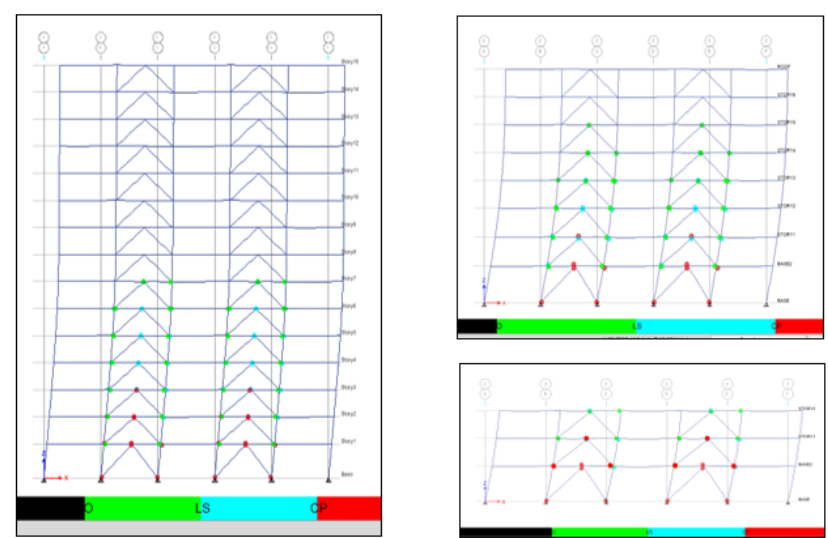

Gambar 12. Formasi sendi plastis push pada saat ultimit struktur lantai 3, 8 dan 15 lantai
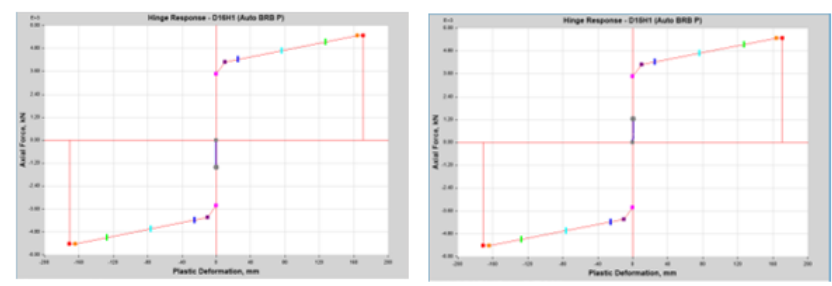

Gambar 13. Kondisi backbone curve pada bresing berada pada kondisi elastik


Gambar 14. Kondisi backbone curve pada bresing berada pada kondisi performance point
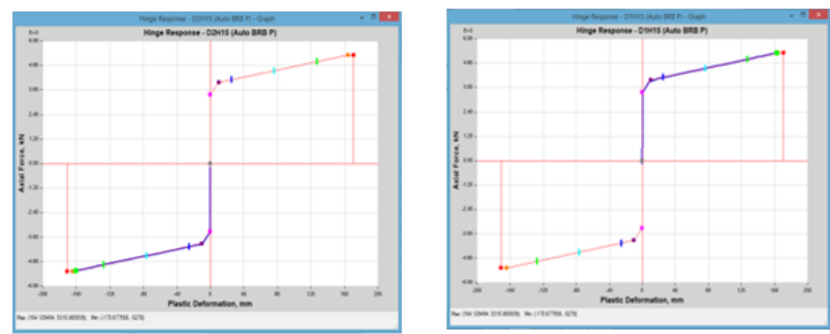

Gambar 15. Kondisi backbone curve pada bresing berada pada kondisi collapse

Dilihat dari backbone curve yang terjadi pada bresing, pada Gambar 13 terjadi pada saat kodisi leleh belum terjadi, pada Gambar 14 bresing berada dalam kondisi performance point dimana level bresing berada pada level Immediate Occupancy (IO) dan pada Gambar 15 terjadi pada saat kondisi ultimit dimana posisi bresing sudah mengalami kegagalan artinya bresing tidak dapat bekerja lagi dan hal ini menunjukkan bahwa tekuk tidak mungkin terjadi pada bresing BRB. 


\subsection{Hasil Analisis Non Linear Time History}

Hasil yang ditinjau meliputi level kinerja gedung dan drift maksimum yang terjadi setelah gedung mengalami beban gempa. Level kinerja gedung ditinjau apakah sudah sesuai dengan level kinerja target gedung yaitu Life Safety (LS) dengan beban gempa maksimum resiko tertarget (MCER). Dalam penelitian ini yang dianalisis dengan NLTH hanya bangunan lantai 15. Ada 3 beban gempa yang digunakan untuk evaluasi masing-masing beban gempa terdiri dari dua data percepatan tanah dengan arah yang orthogonal ( $\operatorname{arah} \mathrm{X}$ dan $\operatorname{arah} \mathrm{Y}$ ) percepatan gempa yang sudah diskalakan dengan respons spektra desain di Jakarta dengan kondisi tanah sedang sesuai dengan Tabel 5 di bawah.

Tabel 5. Percepatan Maksimum dan Durasi dari Data Gempa yang Sudah Diskalakan terhadap Respons Spektra Desain

\begin{tabular}{clcc} 
No. & Nama Gempa & $\begin{array}{c}\text { Akselerasi Maksimum } \\
\text { [g] }\end{array}$ & $\begin{array}{c}\text { Durasi } \\
\text { [detik] }\end{array}$ \\
\hline 1 & Imperial Valley & 0,3587 & 40 \\
\hline 2 & Kobe & 0,3725 & 48 \\
\hline 3 & Northridge & 0,3673 & 40 \\
\hline
\end{tabular}
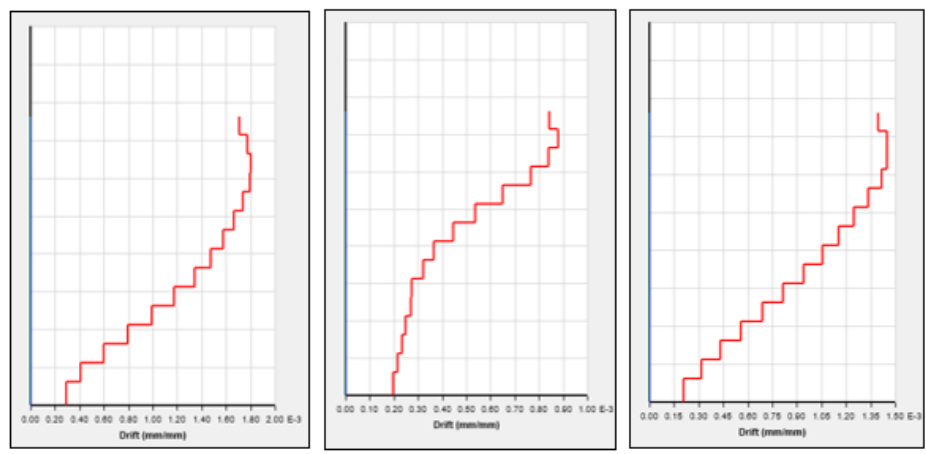

Gambar 14. Drift antar lantai rata-rata arah $X$ hasil NLTHA pada gempa Imperial Valley, Kobe dan Northridge dengan data gempa yang diskalakan dengan respon spektra Jakarta

Dari pola driftyang terbentuk dari ketiga gempa yang sudah diskalakan dengan respon spektra Jakarta jenis tanah sedang mendapatkan pola drift yang tidak seragam artinya drift yang terbentuk dari lantai dasar sampai lantai atas makin besar kecuali pada lantai 11 sampai lantai 15, hal ini disebabkan karena pada lantai atas kekakuan bresing, balok dan kolom lebih kaku dibandingkan dengan lantai dasar sampai lantai 10 . Untuk mengatasi masalah tersebut maka baik kolom, balok dan bresing harus diperkaku dengan mengganti ukuran kolom, balok dan bresing agar memperoleh drift yang seragam dan sesuai dengan dengan ekspektasi yang diharapkan yaitu pola simpangan yang terjadi antar lantai adalah sama.

\section{KESIMPULAN DAN SARAN}

\subsection{Kesimpulan}

Berdasarkan penelitian yang telah dilakukan, dapat diambil beberapa kesimpulan antara lain:

1. Level kinerja yang dihasilkan baik analisis pushover maupun dengan analisis time history pada masing-masing variasi ketinggian struktur adalah Immediate Occupancy (IO).

2. Dari pola kelelehan dan kegagalan struktur yang terbentuk pada struktur dengan ketinggian yang bervariasi (3 lantai, 8 lantai dan 15 lantai) maka dapat disimpulkan bahwa untuk struktur bangunan 3 lantai pendisipasi energi gempa utama adalah pada bresing, hal ini dapat dilihat dari mekanisme keruntuhan yang terjadi bahwa hampir semua bresing telah mengalami kelelehan sebelum terbentuknya kelelehan pertama pada balok, kinerja bangunan akan sangat ditentukan oleh bresing. Untuk struktur bangunan lantai 8 dan 15 bresing bukan merupakan pendisipasi energi gempa utama, terlihat dari jumlah bresing 
yang telah mengalami kelelehan hanya berkisar antara $40 \%$ sampai $60 \%$ sebelum terbentuknya kelelehan pertama pada balok artinya kinerja bangunan tidak sepenuhnya ditentukan oleh bresing.

3. Dari pola drift yang terbentuk dari analisis pushover maupun analisis time history mendapatkan pola drift yang tidak seragam artinya drift yang terbentuk dari lantai dasar sampai lantai atas makin besar kecuali pada lantai-lantai paling atas, hal ini disebabkan karena pada lantai atas lebih kaku dibandingkan dengan lantai bawah. Untuk mengatasi masalah tersebut maka baik kolom, balok dan bresing harus diperkaku, akan diperoleh drift yang seragam dan pola simpangan yang terjadi antar lantai adalah sama.

\subsection{Saran}

Dalam penyusunan penelitian ini dianalisis mengenai akurasi penentuan kinerja struktur bangunan berdasarkan analisis statik pushover dan analisis dinamik time history. Namun hasil yang didapat belum cukup untuk memastikan apakah kedua metoda ini memang bisa digunakan sepenuhnya. Oleh karena itu, beberapa hal yang dapat digunakan untuk pengembangan studi selanjutnya.

1. Analisis dinamik time history dilakukan untuk ground motion gempa yang lebih beragam dan tipe struktur yang lebih beragam.

2. Perlu dilakukan penelitian lanjutan dengan menerapkan capacity design concept.

\section{DAFTAR RUJUKAN}

American Institute of Steel Construction. (2005). AISC 360-05: Specification for Structural Steel Buildings. Chicage: American Institute of Steel Construction.

American Society of Civil Engineers. (2007). ASCE 41-06 Seismic Rehabilitation of Existing Buildings. Reston, V.A.: American Society of Civil Engineers.

Asgarian, B. \& Amirhesari, N. (2008). A comparison of nonlinear behavior of ordinary and buckling restrained braced frames subjected to strong ground motion. The Structural Design of Tall and Special Buildings, 17(2), 367-386.

Badan Standardisasi Nasional. (2012). SNI 1726:2012 tentang Tata Cara Perencanaan Ketahanan Gempa untuk Struktur Gedung dan non Gedung. Jakarta: Badan Standardisasi Nasional.

Bertero, R. \&. (2004). Performance-Based Seismic Engineering: Development and Application of a Comprehensive Conceptual Approach to the Design of Buildings in Earthquake Engineering: From Engineering Seismology to Performance-Based Engineering. Boca Raton, USA: CRC Press.

Chen, C. C., Chen, S. Y., \& Liaw, J. J. (2001). Application of low yield strength steel on controlled plastification ductile concentrically braced frames. Canadian Journal of Civil Engineering, 28(5), 823-836.

Federal Emergency Management Agency. (2000). FEMA 356: Prestandard and Commentary for the Seismic Rehabilitation of Buildings. Washington, D.C.: Federal Emergency Management Agency.

Lopez, W. A. (2004). Seismic Design of Buckling-Restrained Braced Frames. USA: Structural Steel Educational Council (SSEC).

Wada, A. S. (1998). Development of Unbonded Brace in Nippon Steel's Unbonded Braces (promotional document). Tokyo: Nippon Steel Corporation Building Construction and Urban Development Division. 